\title{
Information Technology Payoff in the Health-Care Industry: A Longitudinal Study
}

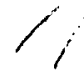

\author{
SARV DEVARAJ AND RAJIV KOHLI
}

SARV DEVARAJ is Assistant Professor of Management at the University of Notre Dame. He received his Ph.D. from the University of Minnesota. He has worked on several projects for companies examining the impact of the technological environment, justin-time manufacturing, work teams, and performance evaluation systems on manufacturing performance. He has also studied the impact of technology investments and technology usage in the health-care industry. In the field of service quality, Dr. Devaraj conducts research on consumers' perception of service and product quality in the automotive industry. He teaches courses in management of technology, operations management, and business statistics.

RaJiv KOHLI is the Project Leader, Decision Support Services, at the corporate office of Trinity Health. He is also an adjunct Assistant Professor at the University of Notre Dame and has taught at the University of Maryland, University College, where he was a recipient of a Teaching Recognition Award. Dr. Kohli received his Ph.D. from the University of Maryland. His research has been published in Decision Support Systems, Information Processing and Management, International Transactions in Operational Research, Journal of Decision Systems, and Health Care Information Management, among other journals. Dr. Kohli's research interests include organizational impacts of information systems, process innovation, and enhanced decision support systems.

ABSTRACT: With the enormous investments in Information Technology (IT), the question of payoffs from IT has become increasingly important. Organizations continue to question the benefits from IT investments especially in conjunction with corporate initiatives such as business process reengineering (BPR). Furthermore, the impact of technology on nonfinancial outcomes such as customer satisfaction and quality is gaining interest.

However, studies examining the IT-performance relationship have been far from conclusive. The difficulty in identifying impacts from technology has been the isolation of benefits of IT from other factors that may also contribute to organizational performance. Furthermore, benefits from technology investments may be realized over an extended period of time. Finally, IT benefits may accrue when they are done in concert with other organizational initiatives such as business process reengineering. This calls for studies that take into account control variables as well as data that span time periods.

In this study, we examine monthly data collected from eight hospitals over a recent three-year time period. We specify propositions that relate investments in IT to performance, and the combined effect of technology and BPR on performance. We draw 
upon the literature in health-care management to incorporate appropriate control variables in the analyses. Our results provide support for the IT-performance relationship that is observed after certain time lags. Such a relationship may not be evident in cross-sectional or snapshot data analyses. Also, results indicate support for the impact of technology contingent on BPR practiced by hospitals.

KEY WORDS AND PHRASES: business process reengineering, health-care information systems, information technology payoff, information technology productivity.

ChANGES IN THE HEALTH-CARE BUSINESS RESULTING FROM CAPITATION and declining reimbursement have led to cost-cutting measures through improved operations. In some cases, failure to cut costs threatens the financial viability of healthcare organizations. While on the one hand investment in IT is seen as an enabler of efficiency and competitiveness, it is also a significant financial investment that, if not linked to improved organizational performance, can hasten the decline of an organization. Given this scenario, the issue of IT payoff has come under close scrutiny.

While IT payoff has long been a subject of research and intense discussion, the results have been far from conclusive $[1,63]$. Payoffs from IT have been and continue to be open to debate in the literature, where it is called the "IT productivity paradox" $[9,12,14,74]$. An issue that has led to the ongoing debate is inadequate methodology applied in researching the IT payoff. Perhaps the most serious issue in measuring organizational performance resulting from IT has been that IT payoff is considered in isolation and separate from other organizational practices.

To some extent, the success of IT implementation is contingent on the organization's environment, such as quality indicators resulting from process redesign initiatives, in addition to financial indicators. To this effect we will demonstrate this contingency perspective using the nature and extent of process-redesign initiatives within healthcare organizations. This study aims to synthesize the literature from IT effectiveness and process redesign by developing a set of propositions. Through a rigorous analysis, we will test these propositions using empirical data collected for the purpose from a set of organizations. This study proposes to contribute to the literature by investigating payoffs from IT investments over time, impact of IT investments on quality indicators, and impact of process redesign and IT investment on both profitability and quality.

\section{Literature and Research Propositions}

THIS SECTION PRESENTS AN OVERVIEW OF THE RELEVANT LITERATURE to frame our propositions linking technology and process reengineering with profitability and quality. We also draw on contingency theory to support the combined effect of technology and process reengineering on organizational performance. Based on the literature review and the empirical data collected, we test our data against four propositions. 


\section{Technology-Profitability Connection—The "IT Paradox"}

Table 1 lists selected studies that have measured the impact of IT on profitability. The studies differed in the level at which data were collected for analysis— that is, the economy level, industry level, or firm level. At the economy level, Baily [4] found that productivity declined in the 1970s, while it grew in the prior two decades. Interestingly, the decline took place during a period that incurred a significant investment in IT. A similar pattern of decline was observed during the 1970s through 1992. Roach [55] confirmed this decline in productivity by measuring the productivity of information workers against that of production workers. While the output of production workers increased by 16.9 percent during the 1970 s through the mid-1980s, the output of information workers dropped by 6.6 percent during the same period. In terms of investment, this trend is discouraging because of the high cost of information workers and the steady growth in their ranks over production workers. In the manufacturing segment of the economy, it was determined that for every dollar invested in IT, a $\$ 0.80$ margin was realized [48]. A later study at the industry level also found that IT investment does not lead to greater productivity than other types of investment [48].

Two studies from Asian countries show some positive results in productivity resulting from IT investment. Tam found that from 1983 to 1991, one of the three researched countries' economies had positive and excess returns resulting from investment in IT. However, productivity was measured by increase in computer capital stock [65]. The results of a study of 12 Asian-Pacific countries found significant payoff resulting from IT investment and challenge the "IT paradox." This study, conducted during 1984-90, indicates significant positive correlation between growth in IT investment and growth in both GDP and productivity. It finds that those countries with higher growth rates in IT investment achieved consistently higher growth rates of GDP and productivity [40].

It should be noted that, although several studies are listed as industry-level, they were conducted across several industries, thus encompassing a significant part of the economy. The industry-level studies have also found mixed results of payoff from IT investments. While some studies found that IT investment, productivity, and growth were positively correlated $[35,39,42]$, others found no significant relationship $[8,39]$.

The results of the firm-level studies generally show a positive IT-productivity relationship. As at the economy and industry-level studies, some firm-level studies also show no evidence of IT payoff. In two such studies Strassman found no correlation between IT investment and productivity or profitability [63, 64]. Sometimes, even when IT spending is shown to improve intermediate variables of organizational productivity such as improved communication leading to the need for reduced inventories [20], it does not necessarily lead to improvements in productivity [7]. However, in a firm-level study Brynjolfsson found that firms that reengineered were significantly more productive than their competitors [10].

In a study of U.S. retail banking, IT capital investment was found to have no real benefits. However, this study concluded that there were high returns from investment in IT labor [52]. A recent study has found that investments in IT capital are a net 
Table 1. A Summary of Selected Studies at the Economy, Industry, and Firm Level, and Key Findings

\begin{tabular}{|c|c|c|c|}
\hline Study & $\begin{array}{l}\text { Level } \\
\text { of study }\end{array}$ & Result & Key findings \\
\hline $\begin{array}{l}\text { Baily [4] } \\
\text { Roach [55] }\end{array}$ & $\begin{array}{l}\text { Economy } \\
\text { Economy }\end{array}$ & $\downarrow$ & $\begin{array}{l}\text { Productivity growth declined in the } 1970 \text { s } \\
\text { Output of the information work dropped while } \\
\text { that of the production work increased during the } \\
\text { same period }\end{array}$ \\
\hline Morrison and Bemdt [48] & Economy & $\downarrow$ & IT does not lead to improved profitability \\
\hline $\begin{array}{l}\text { Kraemer and Dedrick } \\
{[40]}\end{array}$ & Economy & $\uparrow$ & $\begin{array}{l}\text { IT investment in } 12 \text { Asia Pacific countries had a } \\
\text { significant positive correlation with growth in } \\
\text { both GDP and productivity between } 1984 \text { and } \\
1990 \text {. }\end{array}$ \\
\hline $\begin{array}{l}\text { Jorgenson and Stiroh } \\
\text { [33] }\end{array}$ & Economy & $\downarrow B$ & $\begin{array}{l}\text { Productivity growth dropped from } 1.7 \% \text { per year } \\
\text { for the } 1947-73 \text { period to about } 0.5 \% \text { for the } \\
1973-92 \text { period }\end{array}$ \\
\hline Tam [65] & Economy & $\downarrow \downarrow \uparrow$ & $\begin{array}{l}\text { IT investment in firms led to positive and excess } \\
\text { returns (1983-91) in one of the three } \\
\text { economies (Hong Kong, Singapore, and } \\
\text { Malaysia) }\end{array}$ \\
\hline Siegel and Griliches [60] & Industry & $\uparrow \mu$ & $\begin{array}{l}\text { IT investment and productivity growth have a } \\
\text { positive correlation }\end{array}$ \\
\hline Brendt and Morrison [8] & Industry & $\leftrightarrow$ & $\begin{array}{l}\text { IT investment does not lead to any greater } \\
\text { productivity then other types of investment }\end{array}$ \\
\hline Kelley [35] & Industry & $\uparrow$ & $\begin{array}{l}\text { IT investment (in programmable automation } \\
\text { technology) leads to significant efficiency } \\
\text { advantage }\end{array}$ \\
\hline Lehr and Lichtenberg & Industry & $\uparrow$ & $\begin{array}{l}\text { IT intensity and productivity growth during the } \\
\text { period } 1987-92 \text { are strongly correlated }\end{array}$ \\
\hline Koski [39] & Industry/fim & $\leftrightarrow \varepsilon$ & $\begin{array}{l}\text { IT investment by firm's use of advanced } \\
\text { communications technologies and its output } \\
\text { and productivity have no positive relationship }\end{array}$ \\
\hline Strassmann [64] & Firm & $\leftrightarrow$ & $\begin{array}{l}\text { No correlation between IT and return on } \\
\text { investment }\end{array}$ \\
\hline $\begin{array}{l}\text { Dudley and Lasserre } \\
\text { [20] }\end{array}$ & Firm & $\leftrightarrow$ & $\begin{array}{l}\text { IT spending to improve communication and } \\
\text { intormation reduce the need for inventories. } \\
\text { Profitability link was not mentioned. }\end{array}$ \\
\hline Strassmann [63] & Firm & $\leftrightarrow$ & $\begin{array}{l}\text { No relation between IT spending, profits, and } \\
\text { productivity }\end{array}$ \\
\hline $\begin{array}{l}\text { Barua, Kriebel and } \\
\text { Mukhopadhyay [7] }\end{array}$ & Firm & $\leftrightarrow$ & $\begin{array}{l}\text { IT was positively related to some intermediate } \\
\text { measures of profitability, but that the effect was } \\
\text { generally too small to measurably affect final } \\
\text { output. }\end{array}$ \\
\hline Diewert and Smith [19] & Firm & $\uparrow$ & IT led to large productivity gains \\
\hline $\begin{array}{l}\text { Hitt and Brynjolfsson } \\
\text { [30] }\end{array}$ & Firm & $\uparrow$ & $\begin{array}{l}\text { IT led to increased productivity and consumer } \\
\text { surplus, but not higher profitability }\end{array}$ \\
\hline Brynjolfsson [9] & Firm & $\uparrow$ & $\begin{array}{l}\text { Firms that had reengineered were significantly } \\
\text { more productive than their competitors }\end{array}$ \\
\hline Prasad and Harker [52] & Firm & $\leftrightarrow$ & $\begin{array}{l}\text { Additional capital investment in IT may not have } \\
\text { real benefits }\end{array}$ \\
\hline Dewan and Min [17] & Firm & $\uparrow$ & $\begin{array}{l}\text { IT capital is a net substitute for ordinary capital } \\
\text { and labor, i.e., IT investment leads to higher } \\
\text { returns }\end{array}$ \\
\hline $\begin{array}{l}\text { Mukhopadhyay, Rajiv } \\
\text { and Srinivasan [49] }\end{array}$ & Firm/application & $\uparrow$ & $\begin{array}{l}\text { IT investment leads to higher productivity and } \\
\text { quality }\end{array}$ \\
\hline
\end{tabular}

substitute for ordinary capital and labor capital, that is, IT investments lead to greater returns as compared to same level of investment in other forms of capital [17]. Another recent study at the application level of a firm in the U.S. Postal Service found that investments and use of IT led to higher output of mail-sorting facilities [49]. This 
points to a key nuance that investments in IT have to be coupled with the actual use of IT. It is usually assumed, perhaps erroneously, that increased investments in IT lead to increased usage of IT.

The literature on the subject of the IT paradox and why IT has not shown significant value is comprehensive and provides a basis for explaining some of the inconsistency and also offers valuable guidance for future research. Research designs have varied from a cross-section of performance variables to longitudinal data. The duration of data collected and the design of studies also vary significantly. Some research designs gathered data at a point in time for research relationships between productivity and IT investment [53] or three to five annual data points [7, 17, 30, 52]. Without sufficient control variables, annual aggregation of data may fail to account for other influences or factors that can affect the firm. Furthermore, three or five data points may not be sufficient to establish a trend for IT payoff, especially when there are lag effects resulting from IT investment and noticeable payoffs. A data set that includes quarter-level data for three to five years, combined with the corresponding control variables, would furnish sufficient data points and provide meaningful results [49].

Although the variety in variables for IT payoff adds diversity to the question of IT payoff, it is also likely to lead to inconsistent research designs, thus hampering the development of a research tradition in this growing field. Table 2 provides a sampling of recent firm-level studies, variables studied, the duration of the study, and the key findings.

Based on the literature presented above, the connection between IT investments and payoff is not very conclusive. This may be due to factors related to level of study, variables selected, and research design. We attempt to address some of these concerns, beginning with our first proposition:

Proposition 1: Investment in information technology leads to increased profitability of the organization.

\section{Technology-Quality Relationship}

One potential explanation for the mixed results of IT payoff is that the variables collected have varied among the published studies. Financial variables such as return on assets (ROA) [30] and return on investment (ROI) have generally been the mainstay for dependent variables, while capital, labor, operating expenses, and revenues have been widely used as independent variables for investigating IT payoff within organizations $[17,30,52]$. For the control or independent variables, some studies have gathered operational measures such as inventory turnover [7] and associated costs [19] to study the impact of IT.

Other studies have gathered organizational variables such as absenteeism, degree of supervision [49], employee composition [24], and number of years the CIO has been in the position with the organization [53] to study the IT payoff for the firm. Even the issue of whether uniformity of variables is preferred has been debated in the IT effectiveness literature [58]. Health-care profitability studies have gathered independent variables that represent ownership type before and after the prospective 
Table 2. A Summary of Firm-level Studies, Variables Used, Duration of the Study, and Key Findings

\begin{tabular}{|c|c|c|c|}
\hline Study & Variables used & Duration & Key findings \\
\hline $\begin{array}{l}\text { Barua, Kriebel, and } \\
\text { Mukhopadhyay [7] }\end{array}$ & $\begin{array}{l}\text { Capacity utilization, } \\
\text { inventory tumover, } \\
\text { quality, relative price, } \\
\text { and new product } \\
\text { introduction }\end{array}$ & $\begin{array}{l}\text { Annual over } 3 \\
\text { years }\end{array}$ & $\begin{array}{l}\text { IT was positively related to some } \\
\text { intermediate measures of } \\
\text { profitability, but that the effect was } \\
\text { generally too small to measurably } \\
\text { affect final output. }\end{array}$ \\
\hline Diewert and Smith [19] & $\begin{array}{l}\text { Inventory holding costs, } \\
\text { growth rate, purchases, } \\
\text { sales, inventory levels }\end{array}$ & $\begin{array}{l}\text { Quartenly } \\
\text { over six } \\
\text { quarters }\end{array}$ & IT leads to large productivity gains \\
\hline $\begin{array}{l}\text { Hitt and Brynjolfsson } \\
\text { [30] }\end{array}$ & $\begin{array}{l}\text { Value added, IT stock, } \\
\text { noncomputer capital, } \\
\text { ROA, labor expense, } \\
\text { ROE, shareholder } \\
\text { return, IT } \\
\text { stockjemployee, capital } \\
\text { investment, sales } \\
\text { growth, market share, } \\
\text { debt, R\&D stock firm }\end{array}$ & $\begin{array}{l}\text { Annual over } \\
5 \text { years }\end{array}$ & $\begin{array}{l}\text { IT leads to increased productivity } \\
\text { and consumer surplus, but not } \\
\text { higher profitability }\end{array}$ \\
\hline Prasad and Harker [52] & $\begin{array}{l}\text { IT capital, non-IT capital, } \\
\text { IS labor expense, non-IS } \\
\text { labor expense }\end{array}$ & $\begin{array}{l}\text { Annual over } 3 \\
\text { years }\end{array}$ & $\begin{array}{l}\text { Additional capital investment in IT } \\
\text { may not have real benefits }\end{array}$ \\
\hline Dewan and $\operatorname{Min}[17]$ & $\begin{array}{l}\text { IT capital, non-IT capital, } \\
\text { labor expense, value } \\
\text { added, sales, number of } \\
\text { employees }\end{array}$ & $\begin{array}{l}\text { Annual over } 5 \\
\text { years }\end{array}$ & $\begin{array}{l}\text { IT capilal is a nel substitute for } \\
\text { ordinary capital and labor, i.e., IT } \\
\text { investment leads to higher returns }\end{array}$ \\
\hline $\begin{array}{l}\text { Mukhopadhyay, Rajiv } \\
\text { and Srinivasan [49] }\end{array}$ & $\begin{array}{l}\text { Total output, on-time } \\
\text { output, labor hours, } \\
\text { machine hours, level of } \\
\text { automation, } \\
\text { absenteeism rate, } \\
\text { degree of supervision }\end{array}$ & $\begin{array}{l}39 \text { accounting } \\
\text { periods over } \\
3 \text { years }\end{array}$ & $\begin{array}{l}\text { IT investment leads to higher } \\
\text { productivity and quality }\end{array}$ \\
\hline $\begin{array}{l}\text { Prattipati and Mensah } \\
\text { [53] }\end{array}$ & $\begin{array}{l}\text { Number of years } \mathrm{ClO} \text { in } \\
\text { the position, proportion } \\
\text { of software resources } \\
\text { spent on client server } \\
\text { applications, percentage } \\
\text { of software budget spent } \\
\text { on new development. }\end{array}$ & One year & $\begin{array}{l}\text { Highly productive firms spent more } \\
\text { on client-server and less on in- } \\
\text { house application development }\end{array}$ \\
\hline $\begin{array}{l}\text { Francalanci and Galal } \\
\text { [24] }\end{array}$ & $\begin{array}{l}\text { IT investments, clerical, } \\
\text { managerial, and } \\
\text { professional } \\
\text { composition, income per } \\
\text { employee, total } \\
\text { operating expense }\end{array}$ & $\begin{array}{l}\text { 10-year } \\
\text { period }\end{array}$ & $\begin{array}{l}\text { Increases in IT expenses are } \\
\text { associated with productivity } \\
\text { benefits when accompanied by } \\
\text { changes in worker compositions }\end{array}$ \\
\hline
\end{tabular}

"Variable names changed to generic.

payment system (PPS) [25], and not-for-profit status [16]. Past studies in health care have used a number of hospital-related variables in addition to financial measures to determine those factors that affect the profitability of hospitals. Such measures include patient mix, average length of stay (ALOS) of patients, and Herfindahl index of market concentration [71]. Table 3 summarizes studies that have used organizational variables to measure IT payoffs.

The topic of quality has gained renewed importance as a management concept and is often supported by significant investments in IT. There is evidence that firms that have won quality awards outperform similar firms in operating-income-based measures. Furthermore, high-quality firms also are better at controlling costs [29]. Therefore, quality variables are often considered in research on IT payoff $[50,73]$. 
Joulo10 7

Table 3. A Summary of Studies Utilizing Organizational Variables to Measure IT Payoff, and Key Findings

\begin{tabular}{|c|c|c|}
\hline Study & $\begin{array}{c}\text { Organizational } \\
\text { variables }\end{array}$ & Key findings \\
\hline Willcocks and Lester [73] & $\begin{array}{l}\text { Measurement and evaluation of } \\
\text { quality improvement }\end{array}$ & $\begin{array}{l}\text { Elements in the uncertainty about } \\
\text { the IT payoff relate to deficiencies } \\
\text { in measurement at the macroeco- } \\
\text { nomic level and weaknesses in } \\
\text { organizational evaluation practice }\end{array}$ \\
\hline Anderson, Fornell and Rust [2] & $\begin{array}{l}\text { Customer satisfaction and } \\
\text { productivity }\end{array}$ & $\begin{array}{l}\text { Changes in customer satisfaction } \\
\text { and changes in productivity is } \\
\text { positive for goods, but negative for } \\
\text { services }\end{array}$ \\
\hline Antonelli [3] & $\begin{array}{l}\text { Diffusion of IT, effects on the } \\
\text { tradability, divisibility and } \\
\text { transportability of information, and } \\
\text { interaction between receptivity and } \\
\text { connectivity of leaming agents }\end{array}$ & $\begin{array}{l}\text { (1) strong correlation between the } \\
\text { levels and rates of growth in the } \\
\text { use of communication and } \\
\text { business services, (2)The } \\
\text { productivity enhancing effects of } \\
\text { the co-evolution in the use of } \\
\text { business and communication. }\end{array}$ \\
\hline Hendricks and Singhal [29] & $\begin{array}{l}\text { Operating income, assets, sales, } \\
\text { costs, quality award }\end{array}$ & $\begin{array}{l}\text { Firms that have won quality } \\
\text { awards outperform other similar } \\
\text { firms in operating-income based } \\
\text { measures. Quality award winning } \\
\text { firms also control costs better. }\end{array}$ \\
\hline $\begin{array}{l}\text { Myers, Kappelman, and Prybutok } \\
\text { [50] }\end{array}$ & $\begin{array}{l}\text { Quality-service, system, } \\
\text { information; Impact-individual, } \\
\text { work group, organizational; Usage, } \\
\text { user satisfaction }\end{array}$ & $\begin{array}{l}\text { A comprehensive contingency } \\
\text { model for assessing the IS } \\
\text { function should include environ- } \\
\text { mental variables such as industry, } \\
\text { competition, economy; and } \\
\text { organizational variables such as } \\
\text { IS budget, size of is function, } \\
\text { maturity of is function, top } \\
\text { management support. }\end{array}$ \\
\hline Francalanci and Galal [24] & $\begin{array}{l}\text { Worker compensation, IT } \\
\text { expenditure }\end{array}$ & $\begin{array}{l}\text { Increases in IT expenses are } \\
\text { associated with productivity } \\
\text { benefits when accompanied by } \\
\text { changes in worker composition }\end{array}$ \\
\hline $\begin{array}{l}\text { Grover, Teng, Segars, and Fiedler } \\
\text { [28] }\end{array}$ & $\begin{array}{l}\text { Nature and magnitude of } \\
\text { relationships between IT diffusion } \\
\text { and process redesign }\end{array}$ & $\begin{array}{l}\text { Process redesign and IT have a } \\
\text { complex relationship with } \\
\text { productivity, and that these can be } \\
\text { represented by a mediating or } \\
\text { moderating model for difterent } \\
\text { technologies }\end{array}$ \\
\hline Pinsonneault and Rivard [51] & $\begin{array}{l}\text { IT investment and } \\
\text { managerial work }\end{array}$ & $\begin{array}{l}\text { Heavy IT users paid greater } \\
\text { attention to and spent more time } \\
\text { on the information related }\end{array}$ \\
\hline Teo and Wong [67] & $\begin{array}{l}\text { Information quality and work } \\
\text { environment }\end{array}$ & $\begin{array}{l}\text { Improvement in work environment } \\
\text { is positively related to IT } \\
\text { organizational impact but not to } \\
\text { managerial satisfaction. }\end{array}$ \\
\hline
\end{tabular}

Business process redesign or reengineering (BPR), related to the quality principles, has also been examined in relation to IT spending and productivity of organizations [28].

With increased competition and the focus on satisfying customer needs, customer satisfaction is also being researched in IT payoff studies. Health-care and other service organizations do not have the luxury of traditional quality control to ensure product quality prior to delivery, as in manufacturing organizations [21]. Therefore, patients' satisfaction is surveyed to assess the quality of services. Patient satisfaction data have become more important and are now considered one of the outcomes of care. Results of patient satisfaction are also used to identify protocols of care that 
result in preferred clinical outcomes, lower costs, and the highest level of patient satisfaction $[26,38]$.

Thus, there is reason to believe that, in addition to the impact of technology on profitability of the organization, the impact of technology on the quality of services rendered is of equal importance. Thus, our second proposition outlines the technology-quality connection:

Proposition 2: Investment in information technology leads to improved quality of products or services as assessed by measures of customer satisfaction and service or product quality.

\section{Process Reengineering}

While IT payoff continues to be investigated, there have been attempts to create strategies and frameworks that reinterpret or explain contradictory results from past research. Robey [56] presents a number of strategies that suggest scrutinizing the data from past studies and correlating similar studies to examine commonalties among research sites and samples. Another suggestion is to "widen the lens" and examine the results of IT payoff in the context of political theory, organizational culture, institutional theory, and organizational learning theory. Each theory examines organizational change as a process. A process theory view of IT and business value is also proposed by Soh and Markus [62], who suggest that IT use and knowhow are intermediate outcomes and require further research. The process theory model suggests that investment in IT projects, applications, and skill base represent creation of IT assets in an organization. Successful deployment of IT assets leads to IT impacts such as redesigned processes, improved decision making, and improved coordination [22, 37]. It is only when IT impacts are at strategic places in the organizational structure that we will see enhanced organizational effectiveness. It is this organizational effectiveness that most studies have examined through the selection of financial and productivity variables. Soh and Markus argue that, between the IT assets and organizational effectiveness, there can be many "losses" that prevent the organizations from realizing a payoff [62]. The process view of IT payoff is also echoed by Mooney, Gurbaxani, and Kraemer in their framework proposing that firms derive business value from intermediate operational and management processes. They classify these processes along automational, informational, and transformational dimensions. As IT continues to permeate the organization, it has a greater impact on the processes and eventually on the organization [47].

Although most BPR is done with the customer in mind, organizations have realized benefits from BPR ranging from financial benefits to customer satisfaction and growth sustenance. CIGNA Corporation, a multinational, leading provider of insurance and financial services, successfully completed a number of BPR projects and realized savings of $\$ 100$ million. For every $\$ 1$ invested in BPR, it got back $\$ 2$ to $\$ 3$ in benefits. CIGNA accomplished these savings while achieving improvements in customer satisfaction and quality of services. In investigating how CIGNA achieved these results, the case study found that the success in BPR was accomplished by affecting 
changes in the organizational structure and its business practices. The organization redesigned and created self-focused teams and trained generalists to handle customer service. Business practices such as enterprise-wide metrics, application of skills where added value was achieved, and a common view of the customer were implemented [15].

Charles Schwab and Co., an investment broker, reengineered the "cashiering" process to standardize the flow of incoming and outgoing funds across multiple investment lines [44]. Similarly, Florida Power and Light (FPL) was awarded the Deming prize for its quality initiatives and reaped significant savings by developing valueadded processes [57].

Our third proposition, thus, is:

Proposition 3: Organizational factors, such as business process redesign (BPR), have a positive impact on measures of organizational profitability and quality.

\section{Fit Between Technology and Process Reengineering}

The underlying premise in "contingency theory" is the proposition that organizational performance is the result of a "match" or "fit" between factors $[69,70]$. Better performance is realized when there is a good fit, or congruency, between these factors, and not otherwise. In the context of technology investments, contingency theory would suggest that, while technology and organizational practices (such as BPR) may have separate impacts on performance, the two together may also affect performance significantly. In other words, the impact of technology on performance is contingent on whether other organizational processes, such as BPR, were also implemented.

Van de Ven and Drazin stated that one approach to capture the fit between factors in contingency theory is through "interaction" terms [69]. According to Venkatraman, such an interpretation of fit would be consistent with "fit as moderation" [70]. From this perspective, the impact of a predictor variable on performance depends on the level of a third variable. In our context, we posit that the impact of technology on performance depends also on the level or degree of BPR implementation in the organization.

Contingency theory and the notion of "fit" received substantial analytical rigor with Milgrom and Roberts's detailed and analytical examination of fit using the mathematics of complementarity [45]. In terms of complementarity theory, activities are complements if doing (more of) any one of them increases the returns to doing (more of) the others. Specifically, we contend that doing more of BPR increases the returns of investing in technology.

Also drawing upon notions of complementarity, Barua et al. presented a theory called business value complementarity. One of the arguments based on this theory was that investments in IT and reengineering cannot succeed in isolation [5]. Since technology and business processes were viewed as complementary factors, they must be changed in a coordinated manner to improve performance.

The operationalization of the fit between technology and process redesign is an interesting question. The literature offers various forms or perspectives of fit and the analytical operationalization varies according to the form of fit proposed. The per- 
spective that best fits our characterization of the concert between technology and BPR is that of "fit as interaction," since we hypothesize that environments that have significant technology investments if coupled with significant BPR initiatives will result in improved organizational performance. According to this approach, the fit between technology and BPR is tested using the cross-product or interaction between the variables for technology and BPR. If the interaction term is statistically significant, after the main effect of technology and BPR is taken into account, there is evidence that the fit between these two factors matters.

Based on contingency and complementarity theory prescriptions, our fourth and final proposition is:

Proposition 4: The interaction between technology investment and BPR initiatives undertaken by the organizations will have a positive impact on performance. In other words, the impact of technology on performance is higher in organizations where there is a high degree of $B P R$ implementation and lower in organizations where there is lesser BPR implementation.

\section{Research Design}

THE HOSPITALS INCLUDED IN THIS STUDY ARE MEMBERS OF A HEALTH SYSTEM. The health system is a national organization with member hospitals in various markets across the United States. Each hospital is an independent legal entity, each with its own board and financial statements. The member organizations of the health system have combined beds of over 4,000, employ about 20,000 people, and have a total operating revenue of approximately $\$ 1.5$ billion. Most of the hospitals have been providing health care for over a hundred years. The hospitals provide a range of services including acute-care hospitals, extended-care facilities, residential facilities for the disabled and elderly, occupational medicine, and community service organizations.

Our research design, called panel data, consists of data across hospitals as well as over time. As a measure of investment in IT, we collected data for 36 monthly periods from eight hospitals of the health system that had recently implemented a decision support system (DSS) to help evaluate contracts. These contracts estimate costs of expected services and compare them with expected payments. The DSS also helps identify areas of cost-cutting and operational improvements necessary for the hospital's financial viability.

The cross-sectional set of hospitals combined with time-series data is ideal for examining the effect of the usage of IT on measures of profitability and quality, while at the same time controlling for various other factors.

\section{Decision Support Systems (DSS)}

Decision support systems (DSS) are computer systems designed to help improve the effectiveness and productivity of managers [34]. DSS deliver models that can be used systematically to evaluate policies and alternatives [22]. Conventional hospital in- 
formation systems help meet the challenge by providing data necessary for policy formation and outcome measurement. However, integrating those systems with DSS can help managers gain insight into the operations, consider alternatives, and develop business strategies.

Combined with cost information, DSS can be used for operational, managerial, and strategic decision-making. Operational decision-making includes resource allocation, activity-based costing, and such decisions that improve the operations at the patient-care level. Managerial decision making includes cost containment, overall profitability of the department, and integration of departmental services with those of other departments. Strategic uses of a DSS can involve contracting decisions, pricing decisions, and merger/ acquisitions planning [38].

In the organizations included in our study, the DSS plays a critical role in the analysis of data and the identification of areas for BPR. The DSS serves as a repository for the financial, clinical, and quality outcomes for each patient admitted to any of the hospitals for the past several years. Each patient record contains as many as 400 fields describing the status of the patient from the time of admission to discharge. Furthermore, the DSS database is designed to store day-of-stay data; for example, the DSS database can supply information that a certain number of aspirin tablets were given to a cardiac patient on the third day of stay. The DSS data are analyzed to identify "best practices" to be emulated by other hospitals. Benchmarking data are purchased from commercial organization and stored in the DSS, so decision makers can measure their performance with national and regional health care organizations.

With this level of information, the managers are able to conduct analysis of the impact of financial and clinical changes to the patient population. The DSS is also a competitive tool in conducting "what-if" analysis to assess the profitability of contracts for a given patient population.

\section{Dependent Variables}

\section{Measures of Profitability and Quality}

Following previous studies in hospital profitability $[27,41,59,68]$, we chose revenues as a measure of profitability. Traditionally, profitability measures call for subtracting costs from revenue. However, in health care this task is made difficult for the following reasons: (1) most hospitals lack accurate cost accounting systems and often use a constant ratio of cost to charges (RCC) to determine the cost of services. Thus, RCC does not facilitate the analysis of IT payoff as it is a direct transformation of revenue. (2) Costs are also affected by varying contractual agreements - that is, discounts offered by hospitals to insurers, and write-offs toward charity care. Each of these deductions can convolute the traditional profitability measures. (3) With the increase in managed health care, premium revenues are considered as profits and expenses are treated as a charge against such profits. On the other hand, revenues are not affected by contractual agreement with insurers, patients' ability to pay, or with managed health care. 
In order to avoid any bias resulting from patients' varying length of stay, we use two measures of revenue - net patient revenue per day and net patient revenue per admission. All revenue numbers were disguised by multiplying with a constant to protect the confidentiality of the data. The following is a brief description of the measures for profitability and quality:

- Net patient revenue per day (NPRDAY) is the ratio of the total revenue realized by the hospital to the total number of days in the period under consideration.

- Net patient revenue per admission (NPRADM) is the ratio of the total revenue realized by the hospital to the total number of patient admissions during the period under consideration.

- Mortality rates (MORT) is defined as the number of mortalities within 30 days of an operative procedure divided by the total number of operative procedures conducted in the time period under consideration.

- Customer satisfaction (SATIS) is defined as the percentage of "top-box" scores (described below) in the time period under consideration.

Customer satisfaction is measured by independent survey research companies through phone calls made to patients. This ensures the confidentiality of patient responses as well as maintaining the reliability of the data. The questions measuring satisfaction include willingness to recommend the hospital to others, satisfaction with the doctors and nurses, and treatment with dignity, respect, and compassion. Finally, a question solicits overall satisfaction. The correlations of all satisfaction questions with the overall satisfaction question are regularly monitored to ensure that the questions meaningfully capture patient satisfaction. The responses are ranked on a ten-point Likert scale. The patient satisfaction scores in this paper represent top-box scores that is, the percentage of respondents ranking 9 and 10 on the ten-point scale. Top-box ranking is a widely used method for assessing patient satisfaction in the health care field.

\section{Independent Variables}

\section{Technology Investment}

We collected monthly costs associated with IT labor, capital, and support for every hospital. Specifically, we focused on the expenditure involved within the DSS.

- ITLABOR: Our measure for IT labor includes costs associated with total salary and wage expenses for management, supervisors, professionals, administrative and clerical staff.

- ITSUPPORT: The measure for IT support includes (a) consulting fees expense, (b) decision support system computer programming, (c) software support, and (d) decision support system maintenance expense.

- ITCAPITAL: IT capital expenses include cost of the DSS software product and its associated modules. 


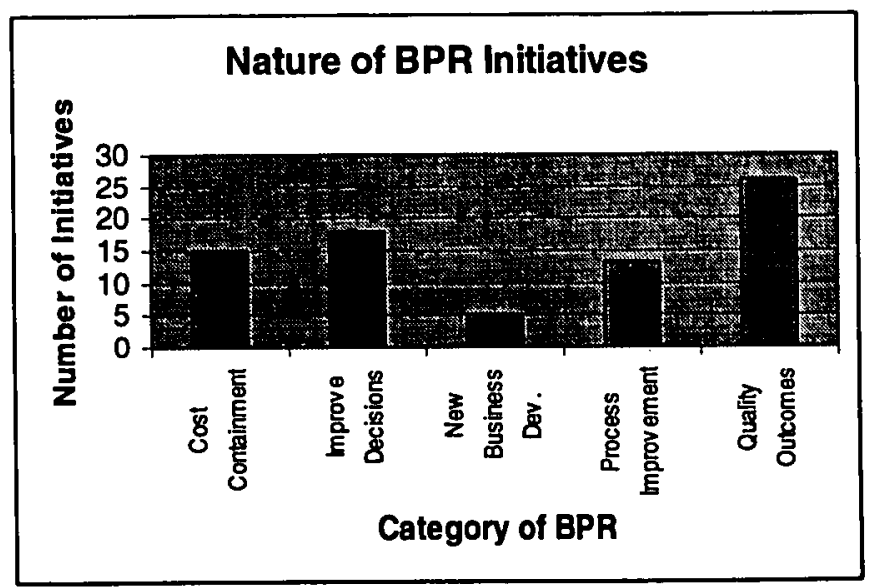

Figure 1. The Nature of BPR Initiatives

\section{Implementation of Business Process Redesign (BPR)}

In health care, the application of BPR has generally focused on cost reduction of clinical and administrative processes [66]. BPR can assist in reengineering patient care by identifying practice patterns that lead to reduced costs, improved quality outcomes, and higher patient satisfaction. These practice patterns, also called treatment pathways, in turn lead to reengineered patient care.

The BPR projects in the organization were focused in a number of areas. These can be categorized in five major areas indicated in the histogram in figure 1. Most initiatives were for improving the quality of outcomes of hospital care. With increased cost cutting, the quality of outcomes such as the length of stay, infection rates and expected versus actual mortality rates are being carefully examined. The second largest number of BPR projects were applied to improve decision-making. An example of improved decision-making is developing a treatment regimen for heart attack patients that leads to the highest survival and rehabilitation rate. Cost containment initiatives include administrative as well as clinical scenarios. The best-quality and lowest-cost physicians for the expensive procedures, such as heart bypass surgery, are identified. The treatment protocols of such physicians are compared with those of other physicians. The breakdown of costs of drugs, prosthetics, and lab tests is then shared with the physician committees. Similarly, patient wait times in the emergency room were studied, and a BPR initiative to install an information system to communicate lab results efficiently to the physician was undertaken.

Process improvement projects were applied in various administrative areas. Given that the reimbursement for patient services is dependent on the accurate coding of diseases and procedures, the process of coding was examined and improved for fair reimbursement from payers. A few BPR projects were initiated to explore and support new services being provided to physicians and patients, some of which had been outsourced in the past.

Over the period of study for the hospitals in our sample the maximum number of 
BPR initiatives under way was 18 , the minimum was 4 , and the average was 12.8 . Given that our study encompassed 77 BPR projects, space considerations prevent us from providing greater detail. Additional detail on the BPR projects is available from the authors.

The following is a detailed example for establishing standards and expected cost savings for knee and hip procedures classified as a Diagnostically Related Group (DRG) 209. From the historical data, we compare actual versus expected costs (from benchmarking) for severity-adjusted DRG 209. Then, a breakdown of the total costs at the departmental level with a focus on high-cost departments is presented to the process engineer. This information is further broken down into individual charge item groups such as supplies, room charges, and other high-cost items. In addition, median cost by departments serving DRG 209 are also calculated. Costs above the median are identified by department and by physician(s). Finally, savings opportunities are identified by bringing the practice patterns to median and benchmark levels, and patient care is reengineered. Other clinical applications of BPR have been in areas of reducing the length of stay [22] and the turnaround time of test orders between the pathology laboratory and the Emergency Department [36]. Similarly, BPR has led to improvements in the billing process by reducing the number of days in Accounts Receivable and thereby improving the cash flow [23].

The empirical literature in BPR has employed various sets of measures, many of which are subjective assessments of managers obtained through surveys. Nevertheless, a common theme among BPR studies is cost reduction and process-time reduction. Because of the diversity of physician practice patterns, process steps or process times in health-care organizations are studied in the light of potential cost reductions.

We conducted in-depth interviews with managers to get their assessment of an appropriate measure of BPR effectiveness. The managers' assessment indicated that, while there were various areas where improvement could be measured, the most important measure of any BPR initiative would be its "impact on the bottom line"in other words, the anticipated cost savings to the hospital. Therefore, we obtained an estimate of the potential cost savings to the organization as a result of implementing a particular BPR initiative. The BPR variable used in this study for a particular hospital for a given time period is the anticipated total cost savings of all the BPR projects under way.

We test the proposition that the greater the extent of BPR, the greater the possibility for improved performance in concert with technology usage (propositions 3 and 4). This measure has the advantage that it is objective and does not rely on the subjective judgment of any individual.

\section{Lag Effects}

In a longitudinal study the effects of the independent variables on performance may be realized after a period of time. Brynjolfsson and Hitt (1998) suggest that "if there is some lag or adjustment time required to match organizational factors and IT invest- 


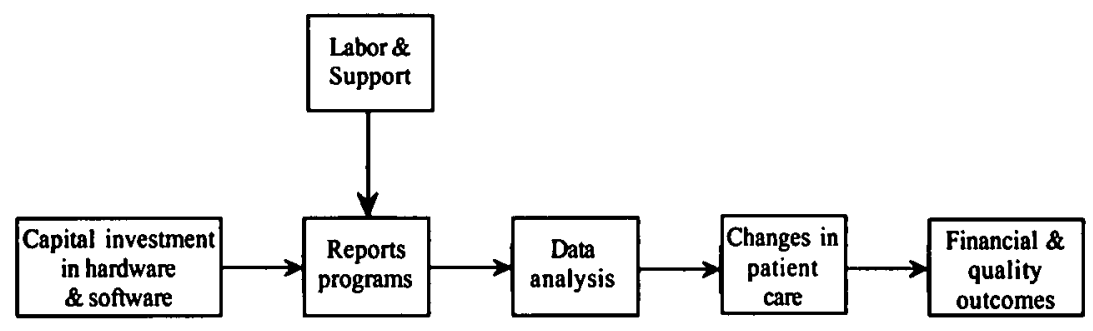

Figure 2. Timeline of IT Investment Impact

ments, we would expect to see more benefits over longer time periods" [11]. Similarly, Mahmood and Mann (1997) state, "Attempts should be made to use a timelagged regression analysis to allow for the fact that benefits derived in a given year may be due to IT investments made in previous years" [44].

Specific lags vary based on the nature of the industry and the processes being considered. While in manufacturing and engineering applications lag effects can be measured in years, the health care industry is likely to experience shorter lags due to the nature of its business. Furthermore, the maturity of the IT infrastructure within the organizations can also affect the duration of lags.

Our discussions with managers at the research site suggested that investments in IT follow a particular chronological sequence in the hospital setting. This is shown in figure 2. The first step is typically an investment in IT capital. This is followed by procurement of software and hardware. The new infrastructure is then used to create and run programs and reports. This stage involves IT labor and IT support as inputs. This is followed by member organizations (hospitals) making changes based on the results of the earlier step. This leads to changes in patient care that eventually lead to better performance on financial and quality outcomes.

Managers were also of the opinion that "investments in IT labor may yield results in terms of improved performance about 2-3 months later due to lead times involved with the technology being in place prior to the programming staff developing the applications." Thus, we chose to incorporate a time lag of three time periods for IT labor and support in our analyses. Since capital enters the equation earlier along the time line (figure 2), we included a four-period lag for IT capital.

Our measure for BPR initiatives captures the anticipated cost savings resulting from BPR implementation. The infrastructure to support such an initiative is already in place, and months of careful planning have already taken place. This is in contrast to startup organizations where the infrastructure deployment can take several months or even years. Thus, in our case it seems reasonable to expect that returns from BPR may be realized without much delay. This was also supported by managers who were responsible for implementing these initiatives. One manager stated that "the impact resulting from the change in practice patterns will appear shortly, approximately 2 months in most cases, because revenue is booked right after the patient is treated. Therefore the lags are primarily due to the physicians incorporating the new process into practice and the time involved in compiling medical and billing records." Therefore, we employed a two-period lag on the BPR variable. 
BPR studies in clinical settings suggest lag effects of four to six months. Shorter lead times in clinical settings can be ascribed to the implementation of "evidencebased practice" that promotes making immediate process changes based on published clinical evidence [61]. For example, process changes in the emergency department resulted in a reduction of laboratory utilization with a lag of six months [18]. In an intensive care unit (ICU), respiratory infections were reduced significantly after a lag of four months of a BPR initiative [31]. Implementation of practice guidelines to reduce lab tests, $\mathrm{X}$-rays, and $\mathrm{EKG}$ exams resulted in improved process and outcomes in less than six months [72].

\section{Control Variables}

Conceivably, the performance of hospitals can be affected by a number of variables other than the investment in IT and process redesign. Therefore, we conducted an extensive literature survey of projects on determinants of health care productivity and profitability. The list and labeling of control variables that we employ in our study reflect the extant literature in health care management $[27,41,59,68]$.

- Service index (CASEMIX): The service index or the casemix index is a measure of the range of services offered by the hospital. The higher this measure, the more complex the services rendered by the hospital.

- Labor intensity (FTE): The number of full-time employees per patient day provides a measure of labor intensity. The relationship between personnel efficiency and profit margins has been of interest to health-care-management researchers and thus should be controlled for.

The next two variables assess the extent to which services offered by the hospital were provided to Medicare and Medicaid patients. The reasons for controlling for these effects were: (1) Medicare and Medicaid payments are typically less than payments from other payers for similar services, and (2) Medicaid and Medicare patients are more costly to treat than other patients [27].

- Medicare (MEDICARE): Percentage of admissions that are Medicare patients compared to total admissions;

- Medicaid (MEDICAID): Percentage of admissions that are Medicaid patients compared to total admissions;

- Outpatient mix (OUTPATNT): There is a general belief in health care management that outpatient services are more profitable than inpatient services. To control for the existence of any such effect on profitability, we include the ratio of outpatient revenue to total revenue as a control variable. ${ }^{1}$

- Per-capita income (INCOME): It is conceivable that with higher patient incomes, hospitals may be able to charge more for their services as well as lose less due to bad debts. For this reason, we included the per-capita income of region/ market for each of the hospitals in the analyses.

A summary of all the variables employed in this study is shown in Table 4. 
Table 4. Definition of Variables Jon0108

\begin{tabular}{|c|c|}
\hline Variable name & Definition \\
\hline NPRDAY & Net patient revenue per day for hospital $i$ during time period $t$ \\
\hline NPRADM , & $\begin{array}{l}\text { Net patient revenue per patient admission for hospital iduring } \\
\text { period } t\end{array}$ \\
\hline MORT $_{\|}$ & Patient montality for hospital iduring period $t$ \\
\hline SATIS & Customer satisfaction performance for hospital iduring period $t$ \\
\hline ITLABOR $_{k}$ & IT labor expenses for hospital iduring period $t$ \\
\hline ITSUPPORT & IT support expenses for hospital iduring period $t$ \\
\hline ITCAP $_{a}$ & IT capital expenses for hospital iduring period $t$ \\
\hline $\mathrm{BPR}_{k}$ & $\begin{array}{l}\text { Measure of the extent of anticipated BPR impact for hospital } i \\
\text { during time period } t\end{array}$ \\
\hline CASEMIX & Case mix for hospital $i$ during time period $t$ \\
\hline FTE $_{i t}$ & Number of full-time employees at hospital $i$ during time period $t$ \\
\hline MEDICARE $_{a}$ & Percent of Medicare admissions at hospital $i$ during time period $t$ \\
\hline MEDICAID, & Percent of Medicaid admissions at hospital $i$ during time period $t$ \\
\hline INCOME $_{k}$ & $\begin{array}{l}\text { Per-capita income of the region/market for hospital iduring time } \\
\text { period } t\end{array}$ \\
\hline OUTPATNT, & $\begin{array}{l}\text { Ratio of outpatient revenue to total revenue for hospital } i \text { during } \\
\text { time period } t\end{array}$ \\
\hline
\end{tabular}

\section{Estimation}

WE EMPLOY TIME-SERIES MODELS TO ESTIMATE THE EFFECT of technology and BPR implementation and their combined effect on various measures of performance. These time-series models account for longitudinal correlation or correlations over time. Equations (1) through (4) were estimated to examine the relationship between technology and performance while at the same time controlling for various extraneous factors through the use of control variables:

(1)

$$
\begin{aligned}
& \text { NPRADM }=\beta 0+\beta 1 \text { ITLABOR(3) }+\beta 2 \text { ITSUPPORT(3) + } \beta 3 \text { ITCAPITAL(4) } \\
& +\beta 4 \text { BPR(2) + } \beta 5 \text { ITLABOR(3) * BPR(2) + } \beta 6 \text { ITSUPPORT(3) * BPR(2) } \\
& +\beta 7 \text { ITCAPITAL }(4) * \text { BPR(2) + } \beta 8 \text { CASEMIX + } \beta 9 \text { FTE + } \beta 10 \text { MEDICARE } \\
& +\beta 11 \text { MEDICAID }+\beta 12 \text { OUTPATNT }+\beta 13 \text { INCOME. }
\end{aligned}
$$

(2)

NPRDAY $=\beta 0+\beta 1 \operatorname{ITLABOR}(3)+\beta 2 \operatorname{ITSUPPORT}(3)+\beta 3$ ITCAPITAL(4)

$+\beta 4 \mathrm{BPR}(2)+\beta 5 \operatorname{ITLABOR}(3) * \mathrm{BPR}(2)+\beta 6 \operatorname{ITSUPPORT}(3) * \operatorname{BPR}(2)$

$+\beta 7$ ITCAPITAL $(4) * \operatorname{BPR}(2)+\beta 8$ CASEMIX + $\beta 9$ FTE + $\beta 10$ MEDICARE $+\beta 11$ MEDICAID + $\beta 12$ OUTPATNT + $\beta 13$ INCOME.

(3) 
$+\beta 7$ ITCAPITAL $(4) *$ BPR(2) + $\beta 8$ CASEMIX + $\beta 9$ FTE + $\beta 10$ MEDICARE $+\beta 11$ MEDICAID + $\beta 12$ OUTPATNT + $\beta 13$ INCOME.

(4)

$$
\begin{gathered}
\text { SATISF }=\beta 0+\beta 1 \text { ITLABOR }(3)+\beta 2 \text { ITSUPPORT }(3)+\beta 3 \text { ITCAPITAL }(4) \\
+\beta 4 \text { BPR }(2)+\beta 5 \text { ITLABOR }(3) * \operatorname{BPR}(2)+\beta 6 \text { ITSUPPORT }(3) * \text { BPR }(2) \\
+\beta 7 \text { ITCAPITAL }(4) * \text { BPR }(2)+\beta 8 \text { CASEMIX }+\beta 9 \text { FTE }+\beta 10 \text { MEDICARE } \\
+\beta 11 \text { MEDICAID }+\beta 12 \text { OUTPATNT }+\beta 13 \text { INCOME. }
\end{gathered}
$$

Net patient revenue per day (NPRDAY) and net patient revenue per admission (NPRADM) are widely used measures of hospital profitability, while in-patient mortality (MORT) and customer satisfaction (SATISF) are measures of quality performance. The direct impact of investments in labor, support, and capital can be estimated by examining the coefficients ( $\beta 1-\beta 3$ ) associated with these terms. The impact of BPR on performance is indicated by coefficient $\beta 4$. Finally, the fit between IT investments in labor, support, and capital and BPR is indicated by the sign and significance of the coefficients associated with the interaction terms in the model $(\beta 5-\beta 7)$. The numbers in parentheses indicate the number of time lags considered for the respective independent variables.

\section{Diagnostic Checks}

We performed several diagnostic checks to ensure that assumptions of the analyses were not violated. First, we captured the residuals from the analyses and tested whether they followed a normal distribution using the Kolmogorov-Smirnov test. The $p$ values that we obtained did not indicate a violation of the normality assumption. The second check we performed was to test for nonconstant variance or heteroscedasticity using White's test. The results did not suggest any issues. We also ensured that autocorrelation or serial correlation was not a problem in the estimation by looking at the Durbin-Watson statistic. Our final check was to test for the presence of multicollinearity. None of the variance inflation factors (VIF) was greater than the threshold value of 10 , suggesting that multicollinearity was not an issue.

\section{Results}

We present descriptive statistics and pairwise correlations between variables employed in this study in Table 5. We observe several significant correlations between variables. We limit our discussion of these correlations only to key relationships because correlations hint at relationships between variables without accounting for the impact of the other variables. The measures for profitability are positively and significantly correlated with each other and also correlated with customer satisfaction. Investments in labor are positively correlated with support and capital, whereas support and capital are not significantly related with each other.

The relationship between IT investments (in labor, support, and capital) and profitability is the subject of proposition 1. An examination of model 1 (presented in Table 6) suggests that labor investment at any time period has a significant effect on net 


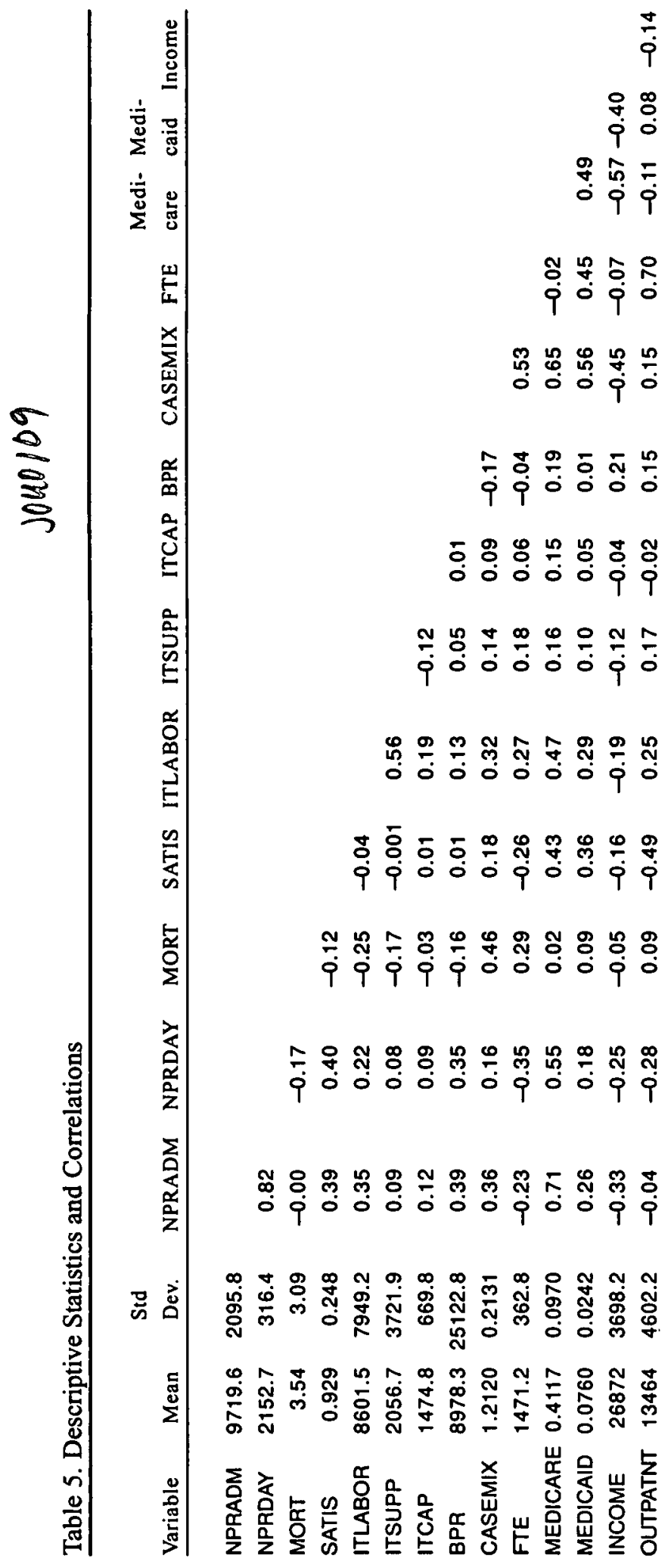


Table 6. Estimation Results for Profitability

\begin{tabular}{llcc}
\hline Reference & Variable & $\begin{array}{c}\text { Model 1 } \\
\text { Dependent } \\
\text { variable } \\
\text { NPRDAY }\end{array}$ & $\begin{array}{c}\text { Model 2 } \\
\text { Dependent } \\
\text { variable } \\
\text { NPRADM }\end{array}$ \\
\hline Proposition 1 & ITLABOR(3) & $0.005^{* *}$ & $0.027^{* *}$ \\
& TSUPP(3) & 0.003 & 0.010 \\
Proposition 3 & TCAP(4) & $0.007^{* *}$ & $0.031^{* *}$ \\
Proposition 4 & BPR(2) & 0.001 & -0.006 \\
& ITLABOR(3)*BPR(2) & -0.001 & 0.009 \\
& ITSUPP(3)*BPR(2) & $0.001^{* *}$ & $0.031^{* *}$ \\
Control variables & ITCAP(4)*BPR(2) & $0.001^{* *}$ & $0.006^{* *}$ \\
& FTE & $-0.429^{* * *}$ & $-2.16^{* * * *}$ \\
& CASEMIX & 233.29 & 2686.48 \\
& MEDICARE & $619.75^{* *}$ & $12973^{* * *}$ \\
& MEDICAID & $1978.00^{* *}$ & $11080^{* *}$ \\
& INCOME & -0.001 & $0.263^{* * *}$ \\
& OUTPATNT & 0.001 & -0.015 \\
& Model R-Square & 0.485 & 0.795 \\
& & &
\end{tabular}

a. The numbers in the table represent coefficients of independent variables.

b. The number in parentheses indicates the number of lags in months of the independent variable.

c. All performance data have been disguised by multiplying with a constant.

${ }^{* * *}$ indicates significance at the $1 \%$ level; ${ }^{* *}$ indicates significance at the $5 \%$ level; * indicates

significance at the $10 \%$ level.

patient revenue per day and net patient revenue per admission three periods later (at the 10 percent and 5 percent levels, respectively). Also, investments in IT capital have an effect on both net patient revenue per day and net patient revenue per admission four periods later (at the 5 percent level). However, we found no evidence of the relationship between IT support activities and profitability.

An examination of the coefficients associated with IT labor, support, and capital on measures of quality is presented in models 3 and 4 (presented in Table 7). IT labor investments in any given period significantly (at the 1 percent level) affect patient mortality three periods later. There was no relationship between IT capital and IT support investments and patient mortality. When the dependent variable is patient satisfaction, the only significant IT component is IT capital (at the 10 percent level) with a four-period lag.

In proposition 3, we articulated the relationship between BPR and organizational performance. Our data analyses suggest that BPR implementations affected both inpatient mortality and patient satisfaction as indicated by models 3 and 4 . This is not to suggest that BPR does not have an impact on financial measures of hospital performance but that the combination of BPR and IT is what really affects financial performance. 
Table 7. Estimation Results for Quality Indicators

Jo40111

\begin{tabular}{llcc}
\hline Reference & Variable & $\begin{array}{c}\text { Model 3 } \\
\text { Dependent } \\
\text { variable } \\
\text { MORT }\end{array}$ & $\begin{array}{c}\text { Model 4 } \\
\text { Dependent } \\
\text { variable } \\
\text { SATIS }\end{array}$ \\
\hline Proposition 2 & ITLABOR(3) & $-0.158^{* * *}$ & -0.006 \\
& TSUPP(3) & 0.001 & 0.001 \\
Proposition 3 & ITCAP(4) & -0.004 & $0.003^{*}$ \\
Proposition 4 & BPR(2) & $-0.439^{*}$ & $0.047^{* *}$ \\
& ITLABOR(3)*BPR(2) & 0.006 & $0.022^{*}$ \\
Control variables & ITSUPP(3)*BPR(2) & 0.001 & $0.042^{*}$ \\
& ITCAP(4)*BPR(2) & 0.001 & 0.001 \\
& FTE & $-4.040^{*}$ & 0.001 \\
& CASEMIX & $19468^{* * *}$ & $-288.17^{*}$ \\
& MEDICARE & $-21714^{* * *}$ & $1488.88^{* * *}$ \\
& MEDICAID & 1559 & $2720.78^{* * *}$ \\
& INCOME & $0.163^{*}$ & -0.001 \\
& OUTPATNT & 0.157 & $0.011^{*}$ \\
& MOdel R-Square & 0.537 & 0.513 \\
& & & \\
\hline
\end{tabular}

a. The numbers in the table represent coefficients of independent variables.

b. The number in parentheses indicates the number of lags in months of the independent variable.

c. All performance data have been disguised by multiplying with a constant.

*** indicates significance at the $1 \%$ level; ** indicates significance at the $5 \%$ level; * indicates significance at the $10 \%$ level.

The combined effect of BPR and investment in IT can be examined by studying the sign and significance of the interaction terms for BPR and each of the IT components included in this study. Models 1 and 2 indicate strong support for the notion of fit between BPR and IT support, and BPR and IT capital. We found a positive and statistically significant relationship between these interaction terms and net patient revenue per day and net patient revenue per admission. When the dependent variables are indicators of quality performance, the interaction terms that are statistically significant (at the 10 percent level) are the interaction between BPR and IT support and IT labor on patient satisfaction.

In the estimated models for measures of profitability, the number of full-time employees is significantly negatively associated with performance, Medicare and Medicaid is positively associated with performance, and income is positively related to net patient revenue per admission. In the models for measures of quality, significant independent variables include case mix, Medicare, Medicaid, patient income, and outpatients. These independent variables are included in the study primarily as control variables and are not the focus of our study. Therefore, for the sake of brevity, we do not discuss detailed implications of these findings.

Given the paucity of a priori theory on time lags in IT-performance studies, we 
conducted a "holdout" sample analysis to test the robustness of our results; the data set was split in two: a "holdout" sample and a test sample. Estimation analyses performed on these two sample groups indicated similar qualitative results (in terms of sign and significance of coefficients). Although our analyses employed the anticipated cost savings from the various BPR projects as a measure of BPR implementation, the results were similar to models that used a count of BPR initiatives. The robustness of the results to the various estimation methods is reassuring and lends credibility to our findings.

\section{Conclusions}

\section{Significance of Investing in IT}

THE RESULTS OF OUR STUDY INDICATE THAT INVESTING IN IT does lead to organizational profitability. Because of our longitudinal research design, we were able to see the lag effects of such investment. We found that the profitability impact is seen in three months or more. We found a stronger IT-profitability link when the patient/ customer's overall profitability was considered, as opposed to per day of stay. This is probably due to the sporadic nature of treatment regimens provided during the patients' stay. We found varying support for investment in IT labor and capital. However, IT investment in consulting and other support services does not appear to have a direct impact on the profitability of the organizations. These findings are similar to the firm-level findings, as in Table 2, in other industries.

We also found support for IT investment's impact on quality initiatives within the organization. We, therefore, found support for propositions 1 and 2 that, in due course, IT investment leads to increased profitability and improved quality of products and services.

\section{Significance of BPR}

The effectiveness of BPR initiatives has been a subject of discussion and controversy within organizations. We find that BPR initiatives lead to reduced mortality and increased patient satisfaction within organizations. As is intuitive, improvements resulting from BPR initiatives do not manifest immediately. Along these lines, we found that improvements in mortality and satisfaction resulting from BPR initiatives in organizations were realized after a period of two months. We did not find any evidence that BPR alone leads to improvement in profitability.

\section{Significance of BPR with IT Investment}

BPR often leads to turmoil within organizations because it demands modifications in how individuals and work processes operate. Therefore, the management and support 
of such change are critical to the success of BPR. In examining the combined effect of BPR and IT investment, we found strong support that it leads to improved profitability for the organization. Specifically, we found that IT support and BPR combined have the strongest impact on the two profitability measures. While no impact was found with BPR and IT labor investment, we did find evidence that IT capital investment combined with BPR affects profitability. These may represent using IT as an enabler for BPR such as a new information system to provide patient information at bedside. Such technologies have shown improved efficiency and effectiveness of patient care. These findings support the recent calls in the literature to study BPR effects in conjunction with the support environment within which BPR is implemented [5, 47,62]. This may also explain the limited support found for proposition 3 (as above).

\section{Limitations}

This study employs data from hospitals belonging to a health system over a recent three-year period. Thus, a principal limitation of the study is the generalizability of the findings reported. Field studies, such as the one reported here, have the advantage of providing a richer operationalization of reality and the ability to track detailed data over time; however their generalizability to the larger population is limited. We do not mean to suggest that findings can be generalized to the larger population of hospitals, even though that may be a possibility. Neither can the findings be generalized to other industries or other organizations.

\section{Future Directions and Research}

Large-sample, cross-sectional studies in conjunction with longitudinal studies are called for to examine the IT payoff issue in detail and to be able to make generalizations across industries, firms, and the like. The random selection of companies through a survey-based approach would allow generalizations across the population of industries or firms under consideration.

The literature in BPR implementation is rife with anecdotal evidence and short on rigorous empirical evidence of performance impacts of BPR. There is a definite need to better measure BPR implementations through objective measures and to relate BPR to organizational performance in the context of other variables that also affect performance.

A more specific area for future research in health care is the impact of IT investments in labor, support, and capital on the continuum of health care. This study is a first step in that direction, but it only examined the impact of IT on acute-care services. Other areas that represent the continuum are ancillary units, freestanding laboratories, outpatient services, and so on.

Finally, an implicit assumption in this study, and in most IT payoff studies, is that investments in IT translate into more usage of the IT, and that this usage results in better organizational performance. The IT usage component is often assumed but is 
empirically untested. This may be an interesting and challenging question for future research endeavors.

\section{Notes}

Acknowledgments: The authors would like to thank Hank Groot for his continued support of the project, Frank Piontek for sharing his experiences and providing suggestions for clinical research, and Don Irmiger, Linda Martin, Doug Anthony, and Diana Utterback for their assistance in obtaining the data.

1. We also computed a measure of competition in the market. This measure, called Herfindahl's index in the health care literature, is computed as a function of the beds in the market and beds in a specific hospital. However, due to minimal variation across the various time periods, the inclusion of this variable presented estimation problems. Hence, we chose to drop this variable from further consideration.

\section{REFERENCES}

1. Ahituv, N., and Giladi, R. Business success and information technology: are they really related? Proceedings of the Seventh Annual Conference of Management IS, Tel Aviv University, Israel, 1993.

2. Anderson E.W.; Fornell, C.; Rust R.T. Customer satisfaction, productivity, and profitability: differences between goods and services. Marketing Science, 16, 2 (1997), 129-145.

3. Antonelli, C. New information technology and the knowledge-based economy: the Italian evidence. Review of Industrial Organization, 12, 4 (1997), 593-607.

4. Baily, M.N. What has happened to productivity growth? Science, 234 (1986) 443-451.

5. Barua, A.;Lee, B.; and Whinston, A. The calculus of reengineering. Information Systems Research, 7, 4 (1996), 409-428.

6. Barua, A., and Lee B. The information technology productivity paradox revisited: a theoretical and empirical investigation in the manufacturing sector. International Journal of Flexible Manufacturing Systems, 9, 2 (1997), 145-166.

7. Barua, A.; Kriebel, C.; and Mukhopadhyay, T. Information technologies and business value - an analytic and empirical investigation. Information Systems Research, 6, 1 (1995), 3-23.

8. Berndt, E.R., and Morrison, C.J. High-tech capital formation and economic performance in U.S. manufacturing industries: an exploratory analysis. Journal of Econometrics, 65, 1 (1995), $9-43$.

9. Brynjolfsson, E. The productivity paradox of information technology. Communications of the ACM, 35 (December 1993), 66-77.

10. Brynjolfsson, E. Technology's true payoff. InformationWeek (October 10, 1994), 34-36.

11. Brynjolfsson, E., and Hitt, L.M. Beyond the productivity paradox. Communications of the $A C M, 41,8$ (August 1998), 49-55.

12. Brynjolfsson, E., and Yang, S. Information technology and productivity: a review of literature. Advances in Computers, 43 (1996), 179-214.

13. Butters, S., and Eom, S. Decision support systems in the health care industry. Journal of Systems Management (June 1992), 28-31.

14. Cameron, K.S., and Quinn, R.E. Organizational paradox and transformation. In R.E Quinn and K.S. Cameron (eds.), Paradox and Transformation: Toward a Theory of Change in Organization and Management. Cambridge, MA: Ballinger, 1988, pp. 1-18.

15. Caron, J.; Jarvenpaa, S.; and Stoddard, D. Business reengineering at CIGNA Corporation: experiences and lessons learned from the first five years. MIS Quarterly, 18, 3 (1994), 233-250.

16. Chang, C., and Tuckman, H. The profits of not-for-profit hospitals. Journal of Health Politics, Policy, and Law, 13 (Fall 1988), 547-564.

17. Dewan, S., and Min, C. The substitution of information technology for other factors of production: a firm level analysis. Management Science, 43, 12 (1997), 1660-1675. 
18. Dickinson, J.C. (1987). From process to policy: a generic prescription for test overutilization in the emergency department. Family Practice Research Journal, 7, 1 (Fall 1987), 12-21.

19. Diewert, W.E., and Smith, A.M. Productivity measurement for a distribution firm. National Bureau of Economic Research Working Paper no. 4812, 1994.

20. Dudley, L., and Lasserre, P. Information as a substitute for inventories. European Economic Review, 31 (1989), 1-21.

21. Ford, R.; Bach, S.; and Fottler, M. Methods of measuring patient satisfaction in health care organizations. Health Care Management Review, 22, 2 (1997), 74-89.

22. Forgionne, G., and Kohli, R. HMSS: a management support system for concurrent hospital decision making. Decision Support Systems, 16, 3 (1996), 209-229.

23. Forgionne, G.; Gangopadhyay, A.; Klein, J.; and Eckhardt, R. Using electronic commerce to improve health care management. Proceedings of the 1998 Association of Information Systems, Baltimore, 1998, pp. 293-295.

24. Francalanci, C., and Galal, H. Information technology and worker composition: determinants of productivity in the life insurance industry. MIS Quarterly, 22, 2 (1998), 227-241.

25. Friedman, B., and Shortell, S. The financial performance of selected investor-owned and not-for-profit hospitals before and after Medicare Prospective Payment. Health Services Research, 23 (1988), 237-267.

26. Furse, D.; Burcham, M.; Rose, R.; and Oliver, R. Leveraging the value of customer satisfaction information. Journal of Health Care Marketing, 14, 3 (1994), 16-20.

27. Gapenski, L.; Vogel, B.; and Langland-Orban, B. The determinants of hospital profitability. Health and Hospital Administration, 38, 1 (1993), 63-80.

28. Grover, V.; Teng, J.; Segars, A.; and Fiedler, K. The influence of information technology diffusion and business process change on perceived productivity: the IS executive's perspective. Information and Management, 34, 3 (1998), 141-159.

29. Hendricks, K., and Singhal, V. Does implementing an effective TQM program actually improve operating performance? empirical evidence from firms that have won quality awards. Management Science, 43, 9 (1997), 1258-1274.

30. Hitt, L., and Brynjolfsson, E. Productivity, business profitability, and consumer surplus: three different measures of information technology value. MIS Quarterly, 20, 2(1995), 121-142.

31. Joiner, G.A.; Salisbury, D.; and Bollin, G.E. Utilizing quality assurance as a tool for reducing the risk of nosocomial ventilator-associated pneumonia. American Journal of Medical Quality, 11, 2 (Summer 1996), 100-103.

32. Jonscher, C. An economic study of the information technology revolution. In T.J. Allen and M.S. Scott Morton (eds.), Information Technology and the Corporation of the 1990s: Research Studies. Oxford: Oxford University Press, 1994, pp. $5-42$.

33. Jorgenson, D.W., and Stiroh, K. Computers and growth. Economics of Innovation and New Technology, 3 (1995), 295-316.

34. Keen, P. Value analysis: justifying decision support systems. MIS Quarterly, 5, 1 (1981), $1-15$.

35. Kelly, M. Productivity and information technology: the elusive connection. Management Science, 40, 11 (1994), 1406-1425.

36. Kohli, R.; Kerns, B.; and Forgionne, G. The application of TQM in a hospital's casualty and pathology departments. International Journal of Quality and Reliability Management, 12,9 (1995), 57-75.

37. Kohli, R., and Forgionne, G. A model to measure DSS effectiveness: theory and empirical analysis. Revue des Systèmes de Décision, 7 (1) (1998), 87-1 10.

38. Kohli, R.; Tan, J.; Ziege, D.; Piontek, F.; and Groot, H. Integrating cost information with health care decision support systems. Topics in Health Care Information Management, 20, 1 (1999), 80-95.

39. Koski, $\mathrm{H}$. The implications of network use, production network externalities and public networking programmes for firm's productivity. Research Policy, 28, 4 (1999), 423-439.

40. Kraemer, K., and Dedrick, J. Payoffs from investment in information technology-lessons from the Asia-Pacific region. World Development, 22, 12 (1994), 1921-1931.

41. Langland-Orban, B.; Gapenski, L.C.; and Vogel, W.B. Differences in characteristics of 
hospitals with sustained high and sustained low profitability. Hospital and Health Services Administration, 41, 3 (Fall 1996), 385-399.

42. Lehr, W., and Lichtenberg, F. Computer use and productivity growth in U.S. federal government agencies, 1987-92. Journal of Industrial Economics, 46, 2 (1998), 257-279.

43. Mahmood, M., and Soon S. A comprehensive model for measuring the potential impact of information technology on organizational strategic variables. Decision Sciences, 22, 4 (1991), 869-897.

44. Mahmood, M., and Mann, G.J. How information technology investments affect organizational productivity and performance: a longitudinal study. Proceedings of the 1997 Information Resources Management Association International Conference, 1997, 187-191.

45. Milgrom, P., and Roberts, J. Complementarities and fit: strategy, structure, and organizational change in manufacturing. Journal of Accounting and Economics, 19 (1995), 179-208.

46. Moad, J. Reengineering report from the trenches. Datamation, 41, 5 (1994), 36-40.

47. Mooney, J.; Gurbaxani, V.; and Kraemer, K. A process oriented framework for assessing the business value of information technology. Database Advances in Information Systems, 27, 2 (1996), 68-81.

48. Morrison, C., and Berndt, E. Assessing the productivity of information technology equipment in U.S. manufacturing industries. National Bureau of Economic Research Working Paper no. 3582, 1991.

49. Mukhopadhyay, T.; Rajiv, S.; and Srinivasan, K. Information technology impact on process output and quality. Management Science, 43, 12 (1997), 1645-1659.

50. Myers, B.; Kappelman, L.; and Prybutok, V. A comprehensive model for assessing the quality and productivity of the information system function: toward a contingency theory for information systems assessment. University of North Texas, Working paper, ISRC-WP-19970101, 1997.

51. Pinsonneault, A., and Rivard, S. Information technology and the nature of managerial work: from the productivity paradox to the Icarus paradox? MIS Quarterly, 22, 3 (1998), 287-311.

52. Prasad, B., and Harker, P. Examining the contribution of information technology toward productivity and profitability in U.S. retail banking. Working paper no. 97-09, Financial Institutions Center, The Wharton School. 1997.

53. Prattipati, S., and Mensah, $M$. Information systems variables and management productivity. Information and Management, 33, 1 (1997), 33-43.

54 . Quinn, J. The productivity paradox is false: information technology improves services performance. Advances in Services Marketing and Management, 5 (1996), 71-84.

55. Roach, S. America's Technology Dilemma: A Profile of the Information Economy. Special Economic Study, Morgan Stanley, 1987.

56. Robey, D. Theories that explain contradiction: accounting for the contradictory organizational consequences of information technology. Proceedings of the Sixteenth International Conference on Information Systems, Amsterdam, December 1995, pp. 55-63.

57. Rutledge, R. Life after the Deming Prize. Business and Economic Review, 40, 3 (1994) 26-31.

58. Seddon, P. A respecification and extension of the DeLone and McLean model of IS success. Information Systems Research, 8, 3 (1997), 240-253.

59. Shi, L. Patient and hospital characteristics associated with average length of stay. Health Care Management Review, 21, 2 (1996), 46-61.

60. Siegel, D., and Griliches, Z. Purchased services, outsourcing, computers, and productivity in manufacturing. In Z. Griliches et al. (eds.), Output Measurement in the Service Sectors. Chicago: University of Chicago Press. 1992.

61. Silagy, C., and Lancaster, T. The Cochrane Collaboration in Primary Care: an international resource for evidence-based practice of family medicine. Family Medicine, 27, 5 (May 1995), 302-305.

62. Soh, C., and Markus, M. How IT creates business value: a process theory synthesis. Proceedings of the Sixteenth International Conference on Information Systems, Amsterdam, December 1995, pp. $29-41$.

63. Strassman, P.A. The Business Value of Computers. New Canaan, CT: Information Economics Press, 1990. 
64. Strassmann, P.A. Information Payoff: The Transformation of Work in the Electronic Age. New York: Free Press, 1985.

65. Tam, K. Analysis of firm-level computer investments: a comparative study of three PacificRim economies. IEEE Transactions on Engineering Management, 45, 3 (1998), 276-286.

66. Teisberg, E.; Porter, M.; and Brown, G. Making competition in health care work. Harvand Business Review, 72, 4 (1994), 131-141.

67. Teo, T., and Wong, P. An empirical study of the performance impact of computerization in the retail industry. Omega: International Journal of Management Science, 26, 5 (1998), 611621.

68. Teplensky, J.D.; Pauly, M.V.; Kimberly, J.R.; Hillman, A.L.; and Schwartz, J.S. Hospital adoption of medical technology: an empirical test of alternative models. Health Services Research, 30, 3 (1995), 437-465.

69. Van de Ven, A.H., and Drazin, R. The concept of fit in contingency theory. Research in Organizational Behavior, $7(1985)$, 333-365.

70. Venkatraman, $N$. The concept of fit in strategy research: toward verbal and statistical correspondence. Academy of Management Review, 14, 3 (1989), 423-444.

71. Vogel, W.; Langland-Orban, B.; and Gapenski, L.C. Factors influencing high and low profitability among hospitals. Health Care Management Review, 18, 2 (1993). 15-26.

72. Wachtel, T.J., and O'Sullivan, P. Practice guidelines to reduce testing in the hospital. Journal of General Internal Medicine, 5, 4 (July-August 1990), 335-341.

73. Wilcocks, L., and Lester, S. In search of information technology productivity: assessment issues. Journal of the Operational Research Society, 48, 11 (1997), 1082-1094.

74. Wilson, D. Assessing the impact of information technology on organizational performance. In R. Banker, R. Kauffman, and M.A. Mahmood (eds.), Strategic Information Technology Management. Harrisburg, PA: Idea Group, 1993. 
Copyright of Journal of Management Information Systems is the property of M.E. Sharpe Inc. and its content may not be copied or emailed to multiple sites or posted to a listserv without the copyright holder's express written permission. However, users may print, download, or email articles for individual use. 